\title{
Engelli Turizminde Turist Rehberliği Uygulamaları Üzerine Niteliksel Bir Araştırma
}

\section{A Qualitative Research on Tourist Guidance Practices in Disabled Tourism}

\author{
Funda ODUNCUOĞLU, Aydın Adnan Menderes Üniversitesi, Türkiye, funda.cengiz@adu.edu.tr \\ Orcid No: 0000-0003-3273-8651 \\ Mahmut EFENDİ, Aydın Adnan Menderes Üniversitesi, Türkiye, efendimahmut926@gmail.com
}

Orcid No: 0000-0002-7388-5239

\begin{abstract}
Öz: Dünya üzerinde tüm bireylerin turizme katılma haklart vardır ve tatile çıkmak engelli ya da engelsiz tüm bireyler için ortak bir gereksinimdir. Engelli bireylerin de engelsiz bireyler kadar özgürce ve sorunsuz biçimde tatil yapabilmeleri için ise turizm sektöründe faaliyet gösteren tüm işletmelere ve işletme çalışanlarına önemli görevler düşmektedir (Ayylldı ve diğerleri 2014:84). Bu önemli görevlerden biri de seyahatleri süresince engelli bireylere eşlik eden rehberlere düşmektedir. Bu bağlamda çalışmanın amacı rehberlerin bu pazara hizmet verebilme konusundaki mevcut düzeylerinin ve pazara yönelik bakış açılarının belirlenmesidir. Bu amaçtan hareketle araştırmada nitel bir araştırma yöntemi olan yarı yapılandırılmış görüşme tekniği benimsenmiş ve 21 rehberi ile yüz yüze mülakat gerçekleștirilmişstir. Araştırma sonucunda turizm sektöründe yer alan tüm işletmelerin engellilerin hareketliliklerini destekleyici bir takım tedbirleri almaları ve onların turizm faaliyetlerinde bulunmaların kolaylaştırıcı bir etki yaratmaları beklenmektedir.
\end{abstract}

Anahtar Kelimeler: Engelli Bireyler, Engelli Turizmi, Turist Rehberliği

JEL Siniflandirmast:Z320,Z380,Z390

Abstract: All the people in the world have the right to participate in tourism and going on a vacation is a common need for all individuals whether they are disabled or not. In order for disabled people to have a holiday as freely and smoothly as the individuals with out disabilities, all the enterprises and employees functioning in the tourism sector have important duties (Ayylldz et all 2014: 84). One of these important tasks falls to the guides accompanying the disabled people during their travels. In this regard, the aim of the study was to determine the current levels of the guides serving this market and their perspectives in terms of the market. Based on this aim, semi-structured interview technique, which is a qualitative research method, was adopted in this researc hand face-to-face interviews were conducted with 21 guides. As a result of the research, it can be stated that all the enterprises with in the tourism sector are expected to take various measures to support the mobility of the disabled individuals and create a facilitating effect so that they engage more in the tourism activities.

Keywords: Disabled Individuals, Tourism for The Disabled, Tourist Guidance

\section{Giriş}

JEL Classification:Z320, Z380, Z390

Dünyada önemli bir azınlığı oluşturan engelli bireylerin de tıpkı sağlıklı bireyler gibi hiç bir ayrımcılığa maruz kalmadan yaşamlarını sürdürebilmeleri en önemli birey haklarından birisidir (Bulgan, 2015: 102). Uluslararası Birleşmiş Milletler Örgütü dünya nüfusunun yaklaşık \%15'inin engelli olduğunu belirtmekte ve engelli bireylerin sayısının, nüfusların

\section{Makale Gecmissi / Article History}

Başvuru Tarihi / Date of Application

: 24 Nisan / April 2020

Kabul Tarihi / Acceptance Date

: 20 Ağustos / August 2020

(C) 2020 Journal of Yaşar University. Published by Yaşar University. Journal of Yaşar University is an open access journal.

There is no conflict of interest or ethical concern regarding this publication. 
yaşlanması ve yaşlı bireylerin engelli hale gelme riskinin yüksek olması ile birlikte daha da artacağını işaret etmektedir. Dünya Sağlık Örgütü verilerine göre dünyadaki toplam engelli nüfusun 2050 yılına kadar 2 milyara ulaşacağı öngörülmektedir (https://www.worldhealt.org). Genel anlamda erişilebilirlik; engelli bireylerin, engelli olmayanlar ile eşit seviyede fiziksel çevreye, ulaşım imkânlarına, iletişim ve bilgi teknolojilerine, eğitim ve diğer tüm hizmet alanları ile etkinliklere ulaşılmasını ifade eder (Popiel, 2014: 56).Turizmde erişilebilirlik ise turistik ürünün kullanımının önünde engellerin olmaması ile ilgilidir. Bu genellikle fiziki ulaşılabilirlik, bilgi ve iletişim ulaşılabilirliği gibi görünse de eğitimsiz personeller de engelliler için ciddi bir sorun teşkil etmektedir (Zeiger, 2011). Engelli bireylerin seyahatleri süresince aldıkları hizmetlere ilişkin yaşadıkları sorunları ve beklentileri konu alan araştırmalar incelendiğinde hizmet alanlarının pek çoğunda olduğu gibi rehberlik hizmetlerine ilişkin de çeşitli sorunların ve beklentilerin olduğu görülmektedir (Daniels ve diğerleri 2005; McKercher ve diğerleri 2003; Shaw ve Coles, 2004; Yau ve diğerleri 2004; Carvalho, 2018). $\mathrm{Bu}$ pazarın geliştirilmesi ve engelli bireylerin katılım ve seyahat tatmin düzeylerinin artırılabilmesi adına turist rehberlerinin bu pazara yönelik bilgi ve bilinç düzeyinin artırılması gerekmektedir (Kabote ve Chikanya, 2017). Niteliksel bir araştırma desenine göre hazırlanan bu araştırmada çalışmanın amacı turist rehberlerinin pazara yönelik bakış açılarının ve sahip oldukları bilgi ve bilinç düzeylerinin tespit edilmesi suretiyle mevcut durumun analiz edilmesi ve elde edilen bulgulardan hareketle pazarın geliştirilmesi adına gerek rehberlerde gerekse sektörde farkındalık yaratılmasıdır.

\section{Engelli Turizmi}

Engelli bireylerin oluşturdukları turizm faaliyeti olarak kabul edilen "engelli turizmi", insanların hareket, görme, işitme ve zihinsel yönden erişimine imkân veren bağımsız ve eşit şekilde evrensel olarak tasarlanmış turizm ürün, hizmet ve çevrelerinin bütünü olarak tanımlanmaktadır (UNWTO, 2013: 4). Darcy ve Dickson (2009: 33) engelli turizmini, engelli bireylerin çevreye bağımlı olmaksızın, eşit ve birey onuruna yakışır bir biçimde evrensel turizm ürünlerine ulaşmalarını sağlayan süreç olarak tanımlamışlardır.

Günümüzde dezavantajlı grup olarak kabul edilen engelli bireylerin turizm faaliyetlerine katılımı oldukça sınırlı sayıda kalmaktadır. Avrupa'da 22 milyon engelli günübirlik turizm faaliyetlerine katılırken, 15 milyon engelli kendi ülkesi sınırları içinde, 8 milyon engelli ise yılda en az bir defa kendi ülke sınırları dışına seyahat etmek suretiyle turizm faaliyetlerine katılmaktadırlar( Yıldız ve diğerleri 2017). Engellilere seyahatlerinde eşlik eden en az bir kişinin daha söz konusu turizm aktivitelerine katıldığı dikkate alındığında engelliler 
Avrupa'da 35 milyon seyahat ve 630 milyon geceleme üretmektedir (Zengin ve Eryılmaz, 2013: 56). Engelli turizminin geliştirilmesine yönelik olarak yapılan hukuki ve altyap1 düzenlemelerinden sonra Avrupa'da engelli turizm pazarının büyüklügü 2014 yılında 786 milyar Euro olmuştur (European Comission, 2013: 26). Engelli bireylerin AB ülkeleri kapsamında gerçekleştirecekleri seyahatlerin 2020 yılında 862 milyon seyahate ulaşabileceği ifade edilmektedir (Özoğul ve Baran, 2017). Avrupa Komisyonu'nun yayınladığı raporda, 2020 yılında turizm faaliyetlerine katılan engellilerin sayılarının daha da artacağı ve buna bağlı olarak engelli turizm pazarının genel turizm pazarı içindeki payının \%25 olacağı öngörülmektedir (Eurpean Comission, 2013:2).

Engelli turistlerin genellikle sonbahar-ilkbahar aylarında seyahat etmeleri, ülkelerin turizm sezonlarını uzatıcı bir etki yaratmakta olup, turizm gelirlerini arttırmak isteyen ülkeler açısından engellileri önemli bir niş pazar konumuna getirmiştir (Bulgan, 2017) . Dolayısıyla herhangi bir engelinden dolayı seyahate çıkamayanların da turizme katılımının teşvik edilmesi önem arz etmektedir (Toskay, 1989: 158). Seyahat ve tatil bu büyük azınlığın, toplumun diğer kesimleri ile kaynaşmalarında önemli bir rol oynarken aynı zamanda turizm endüstrisi için de önemli bir firsat oluşturmaktadır. Bu nedenle turizm sektöründe faaliyet gösteren işletmeler tarafindan bu konuda engellilerin karşılaştığı zorlukların ortadan kaldırılmasına yönelik uygulamaların gerçekleştirilmesi oldukça önemlidir (Poria ve diğerleri 2011).

\section{Engelli Turizminde Sorunlar}

Bireysel açıdan bakıldığında turizm faaliyetlerine katılmak, engelli bireylerin fiziksel ve psikolojik sağlıklarının gelişimlerine katkı sağlamakta ve yaşam kalitelerini arttırmaktadır (Çizel ve diğerleri 2012: 36) ve Birleşmiş Milletler (BM) Engelli Hakları Sözleşmesi ile birlikte hakları dile getirilen engelliler için tüm dünyada "Engelsiz Turizm” düşüncesi giderek yaygınlaşmaktadır (Kilimci, 2008). Toplumdaki tüm bireylerin dinlenme, eğlenme gibi sosyal faaliyetlere katılma hakkı vardır. Bunun yanında engelli bireylerin turizm faaliyetlerine katılımları ve memnuniyetleri açısından, sosyal ve pratik olarak değişik türde bazı güçlüklerin üstesinden gelmeleri gerektiği önemli bir gerçektir (Yaylı ve Öztürk 2006: 88).

Engelli bireyler turizm endüstrisinde faaliyet gösteren işletmelerin sunduğu ürün ve hizmetteki birtakım aksaklıklar nedeni ile seyahat ve tatil satın alma kararından vazgeçebilmektedir. Dünya Sağlık Örgütü (World Health Organization /WHO) (WHO, 2011) 785 milyondan fazla olan engelli nüfusun ulaştırma, konaklama ve bilgi-iletişim kapsamında engellerle karşılaştığını, zor bir şekilde seyahat ettiğini belirtmekte ve diğer bir taraftan 
engellilerin daha bağımsı hareket etmeleri için bazı değişikliklerin yapılması gerektiğini vurgulamaktadır. Figueiredo ve diğerleri (2012: 532) engellilerin turizm faaliyetlerine katılmalarını kısıtlayan engelleri çevresel engeller, iletişim faktörleri ve içsel engeller olmak üzere üç grupta ele almıştır. Engelli bireylerin sahip olduğu fonksiyonel bozuklukların türü ve seviyesi, tatil satın alma talebi veya nasıl tatile çıkılacağı konusu üzerinde farklı etkilere sahiptir (ENAT, 2007).

\section{Engelli Turizminde Rehberlik Uygulamaları}

Engelli turizmine ilişkin yapılan çalışmalarda ağırlıklı olarak engelli bireylerin seyahat motivasyonları, deneyimleri, tatil kararları, engelli turistlerin profili ve işletmelerin engelli turizmindeki mevut durumu vb. konular üzerinde yoğunlaşılmıştır (Shaw ve Coles, 2004; Daniels ve diğerleri 2005; McKercher ve diğerleri 2003). Rehberleri engelli turizmi açısından inceleyen çalışmalar çok az olmakla beraber birçok yazar bu konunun engelli turizmi açısından büyük önem taşıdığına ve ayrıca incelenmesi gereken bir konu olduğuna vurgu yapmaktadır (Daniels ve diğerleri 2005; McKercher ve diğerleri 2003; Shaw ve Coles, 2004; Yau ve diğerleri 2004).

Turizmde rehber, tura katılanları yönlendiren, onlara gidilen yerde ne yapmaları ve neler görmeleri konusunda bilgi veren, onların tatillerinden keyif alması için çalışan ve bireyleri kaynaştıran kişi olarak tanımlanmaktadır (Zillinger, Jonass ve Adolph, 2012). Araştırmalara göre turizm faaliyetine katılan engelli bireyler seyahatlerinde rehber eşliğinde gezmeyi daha çok tercih etmektedirler (Yıldız, Yıldız ve Karaçayır, 2017). Engelliler bireysel olarak seyahat ettiklerinde ve bir tur rehberinden özel hizmet satın aldıklarında, bu rehber için daha kolay bir görev olmaktadır, çünkü rehber sadece bu bireyin ihtiyaçlarıyla ilgilenmektedir. Bunun yanında engelli birey rehberlik hizmetini dahil olduğu grup içinde alıyorsa rehberin görevi ziyaretçilerin birbirinden farklı ihtiyaçlarına aynı anda cevap vermek gerekliliğinden dolayı zorlaşmaktadır, çünkü rehber aynı zamanda grup içinde iyi bir atmosfer oluşturmak zorundadır (Carvalho, 2018). Engelli bireylerin de içinde yer aldığı bir grubu iyi yönetebilmek sadece rehberin profesyonelliği ile de ilgili değildir. Bu bağlamda turun gerçekleştirildiği yerin engellilere uygunluğu, engelli bireylere yönelik sunulan diğer hizmetlerin varlığı(engelli tuvaleti, özel araçlar vb.), çevre koşulları, turdaki diğer engelli olmayan bireylerin tutumu vb. gibi pek çok faktör rehberin başarısı üstünde rol oynamaktadır. Rehberin bu konuda eğitimli ve yetenekli olması engelli bireylerin karşılaşabileceği pek çok güçlügün aşılmasına yardımı olmaktadır (Carvalho, 2018). 
Dünyada giderek önemi artan bu pazarda daha profesyonel hizmet verilmesi seyahat acentalarının bu pazar üzerinde uzmanlaşmasını ve özel eğitimli rehberler eşliğinde turların organze edilmesini gerektirmektedir. Türkiye Seyahat Acentaları Birliği (TÜRSAB) tarafından gerçekleştirilen bir araştırmaya göre Türkiye'de uzmanlık alanlarına göre acenta sayıs1 3359'dur. Bu acentalardan 1182 acenta 38 farklı uzmanlık alanında hizmet sunmaktadır. Bunların içinde sportif/özel ilgi 210 adet ve engellilere özel 69 adet acenta bulunmaktadır ve bu acentaların da ağırlıklı olarak fiziksel engelli bireylere yöneldiği tespit edilmiştir. (TÜRSAB, 2002). Ancak engelli olma hali çeşitlilik göstermekte ve her engel türü birbirinden farklı hizmet ihtiyacını doğurmaktadır. Daniels ve diğerleri (2005: 927), engelli bireyin sahip olduğu engel türüne göre seyahatin tüm aşamalarında bireyin ihtiyaçlarını giderici tedbirlerin alınması gerektiğini belirtmişlerdir.

Engelli turizminde rehberlik hizmetlerini araştıran çalışmalar incelendiğinde, rehberlik hizmetlerinin engelli bireyin tatil memnuniyetini olumlu ya da olumsuz etkileme gücü olduğu net biçimde görülmektedir. McKercher ve diğerleri (2003) Hong Kong'da engelli bireylerin algısı, Arıcı (2010) engellilerin turizm sektöründen beklentileri, Zbikowski ve diğerleri (2011) Engellilerin hangi çeşit tatile ilgi gösterdiği, Chikuta ve diğerleri ( 2017) engelli bireylerin tur rehberlerinden beklentileri ve Zajadacz (2014) işitme engelli bireylerin seyahat özellikleri ile ilgili çalışmalar yapmışlardır.

McKercher ve diğerleri (2003) Hong Kong'da engelli bireylerin seyahat acentelerinin etkinliğine yönelik algılarını inceledikleri araştırmanın sonuçlarına göre, ankete katılanlar çoğunlukla seyahat acentelerinin bu pazarın ihtiyaçlarını karşılamada büyük ölçüde eksik olduğunu belirtmişlerdir. Araştırma sonucunda acentaların engelli turizminde yetersiz oluşuna ilişkin tutumsal ve yapısal olmak üzere iki temel neden tespit edilmiştir. Tutumsal nedenler seyahat acentelerinin engelli insanların ihtiyaçlarından büyük ölçüde habersiz olmasından kaynaklanmakta ve bu durum açık ayrımcılığa yol açmaktadır. Yapısal açıdan ise, Hong Kong'daki perakende seyahat sektörünce paket turlar için belirlenen fiyatların ve içeriklerin engelli turistler için uygun olmayışı ve rezervasyon yapmakta yaşanan zorluklardır.

Yau ve diğerleri (2004) Çinli fiziksel engelli bireyler üzerine gerçekleştirdikleri araştırmada, araştırmaya katılan bireylerin seyahatlerinde bir akrabaları ya da arkadaşları olmadan katılmaları durumunda mutlaka kendileri ile özel olarak ilgilenecek bir tur rehberine ihtiyaç duydukları sonucuna ulaşılmıştır.

Shaw ve Coles, (2004) İngiltere'de yaptıkları araştırmada 1995 yılında yürürlüğe konan Özürlülüğe Dayalı Ayrımcılık Yasasının seyahat acentalarındaki etkisine odaklanmışlardır. Araştırma sonucunda seyahat acentelerinin, engelli turistlerin ekonomik potansiyelinin 
geliştirilmesi bağlamında yasayı destekledikleri ancak engellilerin ihtiyaçlarını anlamakta ve uygun hizmet sunmakta geri kaldıkları sonucuna ulaşmışlardır. .

Daniels ve diğerleri (2005) yaptıkları araştırmada rehberlerin ve seyahat acentası yöneticilerinin engelli turistleri anlama ve onlara yardımcı olmak konusunda yetersiz oldukları sonucuna ulaşmışlarıdır. Araştırmacılar seyahatin her aşamasının engelli bireylerin düşünülerek geliştirilmesinin, tüm gezginler için daha iyi hizmet sağlanmasına yardımcı olacağına vurgu yapmışlardır.

Mahmood ve diğerleri (2020) yaptıkları araştırmada engelli bireylerin seyahatlerini kolaylaştırmada tur rehberlerinin kullanacağı modern teknolojilerin oynadığı rolü ortaya koymayı amaçlamışlardır. Araştırmacılar engelli bireylerin seyahatlerinde yaşadıkları en önemli sorunun erişilebilir bilgi eksikliği ve eğitimli personel eksikliği olduğuna vurgu yaparak, turist rehberleri ile gerçekleştirdikleri anketler sonucunda daha erişilebilir tur deneyimleri sağlamak için rehberlerin elektronik simülasyon programları ve engelli bireylere yönelik dizayn edilmiş elektronik cihazları kullanmak istediklerini ve bunların kullanımının artmasının hizmet sunmalarını kolaylaştıracağı ve daha kaliteli hale getireceği sonucuna ulaşmışlardır.

\section{Yöntem}

$\mathrm{Bu}$ araştırmada tur rehberlerinin engelli turizmine ilişkin bilgi ve bilinç düzeyleri ve pazara bakış açıları belirlenmek amaçlanmış ve bu keşifsel nitelikteki amacı gecçekleştirmek adına veri toplama yöntemi olarak nitel araştırma yöntemlerinden yarı yapılandırılmış görüşme tekniği kullanılmıştır. Çalışmanın evrenini Türkiye'de hizmet sunan profesyonel turist rehberleri oluşturmaktadır. Örneklemi bu evren içinden kartopu örneklem yöntemiyle seçilmiş Kuşadası destinasyonuna tur düzenleyen 21 Turist rehberi oluşturmaktadır. Kartopu örneklem yöntemi aracılığı ile 21 turist rehberine ulaşılabilmiştir. Kartopu veya zincir örnekleme tekniği, evreni oluşturan birimlere erişmenin zor olduğu veya evren hakkındaki bilgilerin (büyüklük ve bilgi derinliği vb.) eksik olduğu durumlarda kullanılmaktadır (Patton, 2005). Eğer araştırmacı diğer satıcılara ulaşmayı başarabilirse araştırmada kullanılan örnekleme yöntemi kartopu örnekleme olacaktır (Creswell, 2013). Bu araştırmada ilk görüşme turist rehberliği yapan bir akademisyen ile gerçekleştirilmiştir. Sonrasında bu katılımcının aracılığı ile ulaşılan 20 turist rehberi ile görüşmeler tamamlanmıştır. Katılımcılardan öncelikle telefon aracılığı ile görüşmelerin gerçekleştirilmesi için randevu talep edilmiş ve her bir katılımcı ile uygun olduğu tarihte 45 dakika ile 1 saat aralığında yüz yüze görüşmeler gerçekleştirilmiştir. Çalışmada katılımcıların Kuşadası destinasyonuna tur yapan rehberlerden seçilmiş olmasının 
nedeni kartopu örnekleme yöntemi ile ulaşılan turist rehberlerinin tur güzergâhlarında Kuşadası destinasyonun bulunması ve kolay erişebilirliktir. Ayrıca farklı bölgelerden turist rehberleriyle görüşme niyeti kartopu örneklem yönteminin kullanılmasından kaynaklanmaktadır. Genel anlamda Türkiye'de bulunan turist rehberlerinin sayısı Tureb internet sitesinde ve Tureb'e bağlı olarak kurulan odaların internet sayfalarında bulunmaktadır. Bunun yanında yıl içerisinde sadece eylemli turist rehberi sayısına ulaşılabilmektedir. Bunun nedeni ise aktif eylemli turist rehberi sayısı bilinse dahi ne zaman ve nerelere tura çıktıklarının bilinmesinin zor olacağı düşünülmektedir.

Toplamda 2020 yılında eylemli 21 turist rehberi ile görüşmeler tamamlanmıştır. Görüşmeler 01.03.2020 ve 15.03.2020 tarihleri arasında gerçekleştirilmiştir. Her bir görüşme veri kaybını önlemek adına ses kayıt cihazı ile kayıt altına alınmak istenmiştir. Bazı turist rehberlerinin daha rahat bir konuşma ortamı istemelerinden dolayı 13 görüşme ses kaydı ile kayıt altına alınmıştır. Diğer görüşmelerde sadece veriler yazıya dökülmüştür. Araştırmada katılımcılara yöneltilen görüşme soruları çalışmanın bulgular kısmında detaylı biçimde soru sırasına göre aktarılmıştır. 21 katılımcıya yöneltilen yarı yapılandırılmış görüşme soruları konuya ilişkin yapılan akademik çalışmalardan ve akademisyen görüşlerinden faydalanılarak oluşturulmuştur. Görüşme formunun ilk bölümünde katılımcıların demografik özelliklerini öğrenmeye ilişkin 4 soru ve 2020 yılında eylemli olup olmadıklarına ilişskin bir evet/hayır sorusu yöneltilmiştir. Görüşme formunun ikinci bölümünde ise turist rehberlerinin engelli turizmine yönelik görüşlerini ortaya çıkarmak amacıyla 8 açık uçlu soru yöneltilmiştir. Açık uçlu sorulardan elde edilen yanıtlar her bir soru için ayrı ayrı değerlendirilerek katılımcıların ortak görüşleri doğrultusunda araştırmacılar tarafından tartışılarak yorumlanmıştır.

\section{Bulgular}

Araştırmaya katılan katılımcıların demografik özelliklerine incelendiğinde, katılımcıların 16 (\%76.19) erkek ve 5 (\%23.81) kadındır. Katılımcıların yaş aralıkları, 21-29 yaş aralığında 1kişi (\% 4.76), 30-39 yaş aralığında 9 (\%42.85) katılımcı, 40-49 yaş aralığında 5 (\%23.80), 50-59 yaş aralığında 4 kişi (19.05) ve 60 yas üzeri 2 kişi (\%9.54)'dir. Katılımcıların eğitim seviyeleri 1 kişi (\%4.76) lise, 2 kişi (\%9.52) önlisans12 kişi (\%57.15) ile ağırlıklı olarak lisans, 5 kişi (\%23.81) yüksek lisans ve 1 kişi (\%4.76)doktora aşamasıdır. Katılımcıların turist rehberi olarak geçirdikleri mesleki süre ise 7 kişi (\%33.34) ile 0-9 yıl aralığında, 8 kişi (\%38.10) ile 10-19 yıl aralığında yoğunlaşmaktadır, ayrıca 5 kişi (\%23.80) ve 1 kişi (\%4.76) 30-39 yıl aralığındadır. 2020 yılında eylemli turist rehberleri dikkate alınmıştır. Demografik sorulardan bağımsız olarak araştırmanın kilit sorularından birisini oluşturan engelli turistler 
ile tura çıkılıp çıkılmadığına ilişkin soruya ise 18 kişi (\%85.71) evet biçiminde yanıt verirken, 3kişi (\%14.29) daha önce böyle bir deneyimleri olmadığı için hayır yanıtını vermiştir. 18 katılımcının ise daha önce böyle bir deneyim yaşamış olması soruların sağlıklı anlaşılarak yanıtlanması açısından yeterli bir sayıdır.

Görüşme formunun ikinci bölümünde katılımcılara yöneltilen 8 açık uçlu soruya ilişkin verilen yanıtlara dayanılarak yapılan yorumlar ve katılımcıların yanıtlarından bu yorumları destekleyenler daha net anlaşılması açısından tablolaştırılarak tablo 1'de.sunulmuştur.

Tablo 1. Engelli Turizmi Tanımı

\section{Soru: Engelli turizmini nasıl tanımlarsınız?}

K1: Engelli bireylerin ve refakatçilerinin katıldığı bir turizm şeklidir. Onlara özel düşünülmüş otel ve eğlence alanlarının yaratıldığı bir çevrede turizm faaliyetlerinin gerçekleştirilmesidir.

K2: kişi yada grubun engeli doğrultusunda hazırlanmış paket yada otel konaklaması.

K3: Seyahat etme ve turistik faaliyetlerde bulunma her birey için haktır. Bu turizm çeşidi engelli bireylerin turistik faaliyetlere katılımının özel bir çerçevede gerçekleştirilmesini ifade etmektedir. Ancak birçok ülkede bu konuda çalışma neredeyse yok denecek kadar az.

K4: Ülkemiz turizminde yeterli hizmeti veremeyip çokhakim olamadığımız turizm hizmeti.

K5: Özel olan kişilere yönelik, onların ihtiyaçlarına yönelik, mobilete ve diğer gereksinimlerinin sağlandığı hizmet sekli.

K6: Fiziksel engeli bulunan turistlerin yaptıkları seyahat.

K7: Onların da, en az tüm diğer tüketiciler kadar bu sektörün seçenekleri ve olanaklarından sonuna kadar yararlanmaları en doğal haklarıdır olgusuna inanıyorum. Engelli Turizmi, turizm dünyasının tüm bileşenlerinin (ister deniz - kum - güneş, ister gastronomi turizmi, ister kültür turizmi, ister sağlık turizmi, ister inanç turizmi, ister doğa turizmi v.d) tüketime, hizmete sunulduğu alanlar, ortamlar, yapılar, tesislerde uygulamada nasıl bir yöntem izleneceğine ve bu ürünlerin, hizmetlerin sunumu esnasındaki tüm ekipmanların (araç - gereç) nasıl kullanılacağına dair bu hizmetleri sunan kurumların ve ilgili tüm personellerin yeterli eğitimbilgi, görgü, teknik bilgi ve tecrübelere sahip olmasını gerektiren düzenlemelerin, yasal mevzuatların, formasyonların bütününü teşkil eden bir Turizm Etkinliği ( onlara, Engelli Vatandaşlarımıza özel ) bir Turizm Pazarı'dır.

K8: Kısıtlı bireylerin turistik gezi ve faaliyetlerine kazandırılması, entegre olması.

K9: Başkalarının yardımı olmadan kendi başına seyahat edemeyecek durumda olan en az bir engeli bulunan kişilerin bir noktadan diğer noktaya seyahat etmesi.

K10: Lojistik zorluğu vardır.

K11: Engelli veya kısmı engelli turistlerle yapılan turistik gezi ve konaklamalardır

K12: Engelli gezginlere uygun şartların oluşturularak seyahat konaklama ve gezilerinin rahatça yapabilmesi.

K13: Fiziksel engeli olan bireylerin fiziksel engellerinin seyahat faaliyetlerine engel olmayacak bir turizm hizmeti olarak tanımlarım

K14: Her bireyin potansiyel bir engelli olduğu dünyada, her iki dünya arasındaki köprüyü kurabilmenin yollarının en büyük adımıdır.

K15: Yürüme engeli, görme ve işitme engelleri bunlardan bazıları. Ülkemizde yaygın olmamakla birlikte bir çok ören yerinde yeni yeni engelli vatandaşların erişimlerine olanaklar sağlanıyor.

K16: Çok önemli bir turizm dall.

K17: Bedensel engelli (işitme, görme engelli vs) bireylerin toplu ya da bireysel katıldıkları turizm hareketi.

K18: Kişi ya da grubun engeli doğrultusunda hazırlanmış paket yada otel konaklaması.

K19: Her destinasyon için giriş çıkış güzergahına kadar farklı gezi önceden planlaması gereken turlardır.

K20: Engelli Bireylerinde normal bireyler gibi tüm turizm faaliyetlerinden yaralanmak istedikleri bir turizm olarak tanımlarım fakat engelli turizm normal turizme göre daha fazla meşakkat isteyen bir turizmdir.

K21: Özel insanların çıkmış olduğu tur olarak.

1.Soru Özet Fikir: Katılımcılara yöneltilen açı uçlu sorulardan ilki onların engelli turizmine ilişkin bakış açılarını öğrenmek üzere yöneltilen "Engelli turizmini nasıl tanımlarsınız (düşünceleriniz nelerdir?)" sorusudur. $\mathrm{Bu}$ soruya ilişkin katılımcıların verdiği yanıtlar incelendiğinde ortak görüşün her tür engel grubunun tanımlamaya ağırlıklı olarak alındığı ayrıca engellilere refakat eden bireylerin de bu turizm türü için de görüldüğü, turizme katılmanın her birey için bir hak olarak görüldüğü, önemli bir turizm türü olduğu ve engellilere yönelik özel alanların ve imkanların sunulduğu bir turizm türü olduğu yönündedir. 
Tablo 2. Engel Türüne Yönelik Hizmet düzeyi

\section{Soru: Farklı engel türlerine yönelik(bedensel, işitsel, görme, zihinsel) hizmet verebilirlik düzeyiniz nedir?}

K1: İşitsel, görme engeli veya zihinsel engelli bireylerin refakatçisi ile sıradan bir turu tamamlaması mümkündür, ancak fiziki veya bedensel engeli olan kimselere normal tur programlarımız araçtan inme binme mecburi yürüme gibi durumlar, oldukça zor olmaktadır. Tamamen engelli bireylere verilecek bir tur hizmetinde ise programı ona göre düzenleyen rehber kolaylık sağlar.

K2: Sabırım vardır ve elimden gelen her şeyi de onlar için yapabilirim. Onların da gezmeye tarihi anlamaya hakları var.

K3: Hiç birine karşı bir eğitimim yok, bu yüzden muhtemelen bu tarz turlar almam.

K4: Orta seviye. Çünkü bu konuda bir eğitimim yok.

K5: Herhangi bir eğitimim olmadığı için düşük.

K6: $\mathrm{Bu}$ söZ konusu bedensel engel, işitsel, görme, zihinsel engellilerin sahip oldukları durumlarına ve ihtiyaçlarına cevap verecek türden hiç bir şekilde, herhangi özel bir eğitim veya oryantasyon almadım. Kendi, şahsi yetilerim ile tur süreci içerisinde, onlar için elimden ne geliyorsa en iyisini yapmaya çalıştım ( tabii onların yanlarında bulunan refakatçileri, ebeveynleri, kardeşleri nezdinde, gözetiminde ve onların onayları dahilinde ).

K7: İşaret dili eğitimi almışım bir ara. Yeterli diye düşünüyorum.

K8: Bu konuda belki odalar eğitim verebilir çünkü gerçekten tecrübe isteyen bir konu hatta engellinin yanında çocuklu ailelerle nasıı tur yapılır konusu da göz ardı edilemeyecek bir durum

K9: Bedensel engelli birine hizmet verebilmek için yeterli düzeye sahip olduğumu düşünüyorum fakat diğerleri farklı bir eğitim sureci gerektiriyor.

K10: Bedensel ve görsel olabilir ancak zihinsel hizmet veremem.

K11: Bedensel engellilere hizmet vermiştim.

$\mathrm{K} 12$ : Bu konuda herhangi bir eğitimim yok maalesef

K13: Hemen her engele sahip misafirlerle gayet keyifli turlar yaptım.

K14: Rehberlik olarak hazır olunsa da; fiziksel koşullar yetersiz. Örneğin, tekerlekli iskemle ile otobüse binilememesi

K15: Nadir karşılaştığım bir durum olduğu için yeterliliğinden emin değilim

K16: Özel eğitimim olmamasına karşın bedensel ve görme ve konuşma engelli vatandaşlara hizmet etmişliğim vardır.

K17: Rehber olarak her tür engelliye hizmet verebilmem mümkün değil, çünkü bu konuda herhangi bir eğitim almadım. Şimdi hatırladım bedensel engelli bir bayana özel Efes turu yapmışım, saatlerce koluma girerek bana tutunarak yürümüştü, o tur benim için çok yorucu olmuştu.

K18: Özel bir eğitimim yok. Ama elimden geleni yapıyorum.

K19: Efes antik kentinde oldukça yüksek memnuniyet derecesinde turlar gerçekleştirdim. Her Destinasyon'un kendi dinamikleri ( arazi eğimi, tekerlekli sandalyeye uygun zemini yada uygun bölümleri, Destinasyon'un büyüklüğ̈̈...) söz konusudur.

K20: Maalesef işitsel, görme ve zihinsel engelliler için hiç bir akademik eğitimim yok.

K21: Özel bir eğitim almadım ama elimden geleni yaparım.

2. Soru Özet Fikir: İkinci soruya katılımcıların verdiği yanıtlar genel olarak değerlendirildiğinde en çok üzerinde durulan konunun engelli bireylere yönelik bir eğitim almamış olmalarının bu tür turlara yönelik kendilerini yeterli hissetme düzeylerini olumsuz yönde etkilediğidir.

\section{Tablo 3. Engellilere Yönelik Eğitim Bilgisi}

\section{Soru: Engelli bireylere yönelik rehberlik etme konusunda bir eğitim aldınız mı?(bu} konuda uzmanlaşma sertifika/eğitim vb. bir program açılır ise katılır mısınız?)

K1: Elbette ki katılmak isterim, henüz almadım.

K2: Sertifika almadım fakat 2-3 seminere gittim. Fikir sahibi olmak için.

K3: Almadım. Açılırsa muhakkak katılırım.

K4: Hayır almadım. Katılabilirim.

K5: Hayır almadım, katılmayı düşünebilirim.

K6: Hayır, almadım. Müsaitliğim olursa katılırım.

K7: Program katılımı isterim ve desteklerim.

K8: $\mathrm{Bu}$ söz konusu bedensel engel, işitsel, görme, zihinsel engellilerin sahip oldukları durumlarına ve ihtiyaçlarına cevap verecek türden hiç bir şekilde, herhangi özel bir eğitim veya oryantasyon almadım. Kendi, şahsi yetilerim ile Tur süreci içerisinde, onlar için elimden ne geliyorsa en iyisini yapmaya çalıştım ( tabii onların yanlarında bulunan refakatçileri, ebeveynleri, kardeşleri nezdinde, gözetiminde ve onların onayları 
dahilinde ).

K9: Almadım. Katılırım.

K10: Hayır almadım, katılırım.

K11: Eğitim almadım Açılırsa katılırım.

K12: Belge almadım açılırsa katılırım.

K13: Almadım. Evet katılmak isterim.

K14: Bu konuda herhangi bir eğitimim yok maalesef.

K15: Hayır almadım. Seve seve katılırım.

K16: Hayır almadım. Kesinlikle katılmak isterim.

K17: Engelli bireylere yönelik rehberlik etme konusunda bir eğitim almadım. İşaret dili kursuna katıldım. Bir program açılırsa katılmak isterim.

K18: Engelli turları eğitiminin oldukça yerinde bir karar olduğunu düşünüyorum. Bu konuda bir eğitim almadım. Bu turların potansiyellerinin yüksek olduğunu deneyimlemiş bir rehber olarak biliyorum. Katılmak isterim.

K19: Almadım. Katılırım. Özellikle işaret dilini öğrenmeyi hep istemişimdir.

K20: Engelli bireylere yönelik rehberlik konusunda özel bir eğitim almadım fakat bu konuda uzmanlaşma eğitimi veya programı açılırsa katılmak isterim.

K21: Kesinlikle bu pazarın gelişmesi adına eğitim programlarının açılması gerektiğini düşünüyorum. Farklı engel türlerini içerirse her engel türü ile ilgili eğitime katılmak ve bilgilenmek isterim.

3. Soru Özet Fikir: Katılımcıların üçüncü soruya verdikleri yanıtlar genel olarak değerlendirildiğinde, hemen hemen tüm katılımcıların engelli turizminin önemli bir Pazar olduğu ve bu pazarda rehberlik hizmetinin sağlıklı ve başarılı biçimde verilebilmesi adına mutlaka farklı engel türlerini içinde barındıran eğitimlerin akademik bir bakış açısıyla rehberlere verilmesinin gerekli olduğunu belirtmişlerdir.

Tablo 4. Turist Rehberinin İşini Zorlaştıran Faktörler

\section{Soru: Engelli bireylere rehberlik ederken işinizi zorlaştıran faktörler var mıdır? Nelerdir?}

K1: Zaman yönetimi olur muhtemelen, sağlıklı bir bireyle yaptığımız tura göre çok daha fazla zaman alır ve turistik yerlerdeki her yere gitme görme imkanımız olmaz, engel türüne göre değişiklik göstermekle birlikte.

K2: Normal bireylerde kendinize göre hareket edersiniz daha çok, fakat engelli bireylere tur yaparken, turun her bir aşamasında ve detayında misafirlerin engellerini dikkate alarak hareket etmek gerekmektedir.

K3: Engelli turistlere kolaylık sağlamak için hizmetlerin yetersizliği. Örneğin Efes ören yerinde tekerlekli sandalye ile hareket etmek oldukça zor ve bu konuda çalışma yok.

K8: Ören yerleri ve ulaşım araçlarındaki teknoloji alt yapı yetersizliği, rehber ve acentelerin gerekli donanım yetersizliği.

K4: En büyük engel ören yerlerinin engellilere yönelik yürüme parkurları olmaması.

K5: Henüz yapmadığım için pek fikrim yok ama iletişim konusunda zorlanabileceğimi düşünüyorum. Altyapı eksikliği en büyük faktör olacaktır.

K6: Mutlaka zorluklar olacaktır. Bu yüzden eğitim almak gerekir diye düşünüyorum.

K7: Mobilite hareket güçlüğ̈̈.

K8: Grupla beraber iken tur süresince, onlara ayrıca, yani onlar için onların durumuna mücbir sebep' ten ötürü eğer fazladan zaman harcarsam ve biraz fazla yakın ilgi gösterirsem, onların dışındaki, grubun diğer üyelerinin bir süre sonra tepkisini çekiyor. Gergin bir hava oluşturuyor, açıkçası çekememezlik durumu bir süre sonra illa ki söz konusu oluyor, üstelik grubun geri kalanına kesinlikle hizmetimi ve ilgimi de aksatmadan vermeme, göstermeme rağmen. Onların ( grubun normal bireylerinin ) yaklaşımları işimi zorlaştırıyor, bir de bazı bedensel engellilere ( örneğin görme engelli, duyma engelli misafirlerimize ) nasıl bir yöntem - metod ile teknik kullanacă̆ımı, spesifik olarak nasıl bilgi, hizmet ve sunum yapacağımı, onları gezdirdiğim yerler hakkında nasıl tam olarak aydınlatabileceğimi bilmiyorum, bunlar da işimi zorlaştıran faktörlerdir.

K9: Program gereği zaman ayarlaması sorun çıkarabilir.

K10: Rehberlik yapılan yer ve mekânın bahsi geçen engel konularına ergonomik olması gerekir.

K11: Çevresel faktörler en önemlisi. Çünkü bireylerin kırıcı bakışlarına maruz kalmak, gezerken aynı anda moral bozucu olabilir.

K12: Bazı Ören yerlerinin yürüyüş alanlarının tekerlekli sandalye için uygun olmaması.

K13: Tekerlekli sandalye için müzeler yollar ve ulaşım araçları hazırlıksız.

K14: Ziyaret edilen yerin yeteri kadar engelli turistleri düşünmemiş olması, rampa vb. gibi önlemlerin alınmamış olması, görme engelliler için eser veya nesnelerin dokunmaya müsaadeli olmaması.

K15: Ören yerlerinin bu hizmet için elverişsiz olması en büyük sorun olur muhtemelen.

K16: Grubun içerisinde tahammül seviyesi yüksek, eğitim ve kültür düzeyi yüksek bireyler olduğu zaman herhangi bir zorlanma yaşamıyorum. 
K17: Engelsizlerle aynı gurupta olmaları.

K18: Ören yerlerinin yetersizliği en büyük engel olmakta. Bedensel engelli misafirler de tekerlekli sandalye ve ya scooter aracı ilerletme tahmin edildiğinden daha zor bazı durumlarda imkânsız. İşitme ve /ve ya konuşma engelli misafirler de ise belli bir seviyeye kadar anlatım yapabiliyorum.

K19: Bazen engelli müşteriyi ilk gördüğümüzde eyvah bugün ne yapacağız diye düşünsekte (gezilecek yerin zorluğuna göre) genel olarak gün içerisinde kendi ve yakınlarıyla ortak çalışmayla zorlukları aşıoruz.

K20: Arazi koşulları, engelli kişi ve refakatçısı dışında tura katılanlar varsa turu herkese uygun duruma getirmek, zaman ayarlaması ( engelli turları daha yavaş ilerleyen turlardır.), tur programının bazen yoğun içerikli olması ( tur programının engelli bir Turiste yönelik olduğunu göz ardı eden acentalar), Araçların engelli turiste uygun olmaması ( tekerlekli sandalyede olan turist için araçta kesinlikle lift gerekmektedir. Aksi durumda yaralanma sözü konusu olabilir ya da tur kaptanında turistin varış ve ayrılışlarda yardımı ciddi sikıntılar yaratabilir.

K21: Tabiki engelli bireylere rehberlik yaparken işimizi zorlaştıran faktörler var. Bunlar yeterli sayıda engellilere yönelik turizm araçları bulunmamaktadır. İkincisi konaklama tesislerinde yeterli sayıda engellilerin konaklaması için bazen oda bulunamıyor. Üçüncüsü ise; müze ve ören yerlerinin engelli bireylere yönelik pek düzenlemenin bulunmaması.

4.Soru Özet Fikir: Dördüncü soruya ilişsin katılımcıların yanıtları incelendiğinde belirtilen görüşlerin benzeştiği ve ayrıldığı noktalar olduğu görülmektedir. Bir grup katılımcı soruyu özellikle fiziksel engelli bireyler ile gerçekleştirilen turlar kapsamında ele almıştır. Bu noktada yaşanan en büyük sorunları; mobilite, tekerlekli sandalyeler ile rahat hareket edememe, ören yerlerinin fiziksel engelli ve özellikle tekerlekli sandalye kullanan bireyler için uygun koşullara sahip olmaması olarak belirtmişlerdir. Ayrıca ören yerlerinde yürüme parkuru ve asansörlerin yetersizliği olarak değerlendirmişlerdir.

\section{Tablo 5. Engelli Turizminde Rehberlerin Önem Düzeyi}

\section{Soru: Engelli turizminde rehberlerin önem düzeyi sizce nedir?}

K1: Yüksektir. Sıradan bir gruba göre daha fazla operasyon, çaba ve sabır gerektirebilir. Elbette belediyeler, hükümet, bakanlıklar ve diğer kuruluşların engellilerin ulaşımı ve erişimi için yapacakları önemlidir. Bu hizmetlerden en iyi faydalanmaya da rehber aracılık edecektir.

$\mathrm{K} 2$ : Bence çok önemli bir husus o kişilere yardımcı olabilmek için.

K3: Bilinçli bir rehber olmak ve karşılaşılacak problemleri çözebilmek önemlidir. Rehber bölgeyi daha önceden bildiği için gerekli tüm tedbirleri alabilir.

K4: Bir hayli yüksek olduğunu düşünüyorum.

K5: Oldukça önemlidir. Örneğin birey çok yaşlı ve engelli olarak Topkapı sarayı ziyareti gerçekleştirmek ister zira ölmeden önce kutsal emanetleri görmek arzusundadır. Burada rehberin sabrı ve bu konudaki donanımı müşteri memnuniyeti kaygısından daha ziyade insanlık vazifesidir.

K6: Rehberlerin engelli turizm açısından eğitilmesi işleri kolaylaştıracaktır.

K7: Elbette önemlidir, diğer misafirlere nasıl bir hizmet kalitesi uygulanıyor ise aynısını engelli misafirlerimiz içinde uygulamalıyız.Çünkü her insan bir engellidir.

K8: Elbette önemlidir, diğer misafirlere nasıl bir hizmet kalitesi uygulanıyor ise aynısını engelli misafirlerimiz içinde uygulamalıyız. Çünkü her insan potansiyel bir engellidir.

K9: Karşınızdaki kişi/ler ile çok iyi empati kurmanızı, peş peşe oluşan farklı durumlara göre ince düşünmenizi zorunlu kılar. İşte tüm bu duygusal gel - git' leri,bu sürprizlerle dolu, bu yıpratıcı süreci her zaman pozitif bir yaklaşım ile bir Profesyonel Turist Rehberi çok iyi yönetebilmek, ihtiyaçlara anında veya en kısa sürede cevap vermek zorundadır. Ve bu beceriyi aksatmadan gösterebilmek bir Profesyonel Turist Rehberini o engelli' nin yanında refakatçi olarak Tur' a gelmiş en az ebeveyni, kardeşi, arkadaşı kadar önemli kişi yapar. Engelli Turizmin' de, Rehberlerin önemi budur bence.

K10: Bizim önem derecemiz hayati çünkü turist ve ören yeri veya müzeyi buluşturan nerede nasıl davranılması gerektiğini bilen ve onları yönlendiren biziz.

K11: Tecrübe etmediğim için net bir yanıt veremem.

K12: Katıldıkları turlarda onları rahatlatacak en önemli unsurdur.

K13: Rehberler kültürler arası köprüyü oluştururlar. Sadece engelli bireyler değil tüm misafirlerin turlarını turist rehberleriyle yapması turun kalite düzeyini artırmaktadır.

K14: Rehberlik tatilin em önemli an ve anılarındandır. Konforudur. Bu durumda önemli bir wrkwndor rehberlik bu bağlamda.

K15: Turizmin her alanında olduğu gibi engelli turizminde de rehberler önemli. Yeteri kadar mesleki düzeyde eğitimler organize edilmeli.

K16: Bence rehberin önem düzeyi engelli türüne göre değişir, zihinsel engeli olanlar rehberin anlatımını yada emeğini ne kadar algılayabilirler acaba? Bunun ya 1sıra, engellilerin herbirinin tekerlekli sandalyesini iten birer sorumlusu olan bir turumda normal kişilere yaptığım turdan farksız bir tur olmuştu, bu yüzden grubum için ben 
önem düzeyim olmadı gerektiği gibiydi.

K17: En önemli kişilerden biri rehberdir. Çevre ile iletişimde sıkıntılar doğabilir.

K18: Rehberlik anlatım dışında bir de uzun bir tur ise çok ciddi otokontrol ve pratik çözüm üretme yeteneği sağlıyor insana. İlk başta bu güveni sağladıysanız rehber hele bir de engelli turizmi için sağlam bir temeldir.

K19: Bir çok rehber arkadaşımın ( bazen Acenta tarafindan önceden belirtilmemiş olabilir.) Efes antik kentinde ciddi sıkıntılar yaşadığına tanıklık ettim. Tur hem rehbere hem de turiste eziyete dönüşebilmektedir. Sonuç olarak rehber için turun hemen bitirmek için çabaladığı bir işe dönüşmektedir.

K20: Gerekli eğitimi (işaret dili, dudak okuyabilen misafirlere yönelik servis vs) almış bir rehber bu engellilere sahip olan bir misafirin kültür turizmini bir hiçten unutulmaz biz ziyarete çevirebilir.

K21: Engelli turizmde rehber oldukça önemlidir. Çünkü engelli turizm oldukça çaba gerektiren bir turizm olduğu için rehberin yeterince sabırlı olması ve empati yapabilmesi önemlidir.

5. Soru Özet Fikir: Beşinci soruya katılımcıların verdiği yanıtlar incelendiğinde genel olarak tüm katılımcıların rehberlik hizmetlerinin engelli bireyler ile gerçekleştirilecek turlarda yüksek önem taşıdığını belirttikleri görülmektedir.

\section{Tablo 6. Ziyaret Alanlarının Engellilere Yetersizlikleri}

\section{Soru: Ziyaret edilen alanlarda (müze, ören yeri, şehir turları vb.) engellilere yönelik} düzenlemeler sizce yeterli midir? (yeterli olan ve olmayan yönleri yazar mısınız?

K1: Efes gibi doğa içerisinde yer alan ve yapılaşmaya izin verilmeyen yerler için düzenlemeler yetersizdir. Müzelerde bu sorun aşılmış durumda. Asansörlü taşıyıcılar veya yürüme yolları gibi benzeri önlemler alındığını gördüm.

K2: Kapalı müzelerde genel olarak koşullar iyi fakat özellikle açık hava müzelerinde bir hayli eksik durumda.

K3: Yeterli değil, işitme engelliye video ile gösterim vb.

K4: Yeterli değil. Tekerlekli sandalye için uygun olmayan parkurlar, engelliler için uygun olmayan araçlar (otobüs VS) engellilere hizmet vermek için donanım sahibi olmayan rehberler sayılabilir. Ancak otellerin birçoğu bu konuda yeterlidir denilebilir.

K5: Hayır yeterli değil, teknoloji ve alt yapı yetersizliği.

K6: Araçların çoğunluğu engelli misafirler için uygun değil. Ören yerlerinde onlar için düzgün bir parkur yok. Altyapı yok kısacası. Basit olarak tekerlekli sandalye bulamıyorsunuz, bulsanız dahi engelli kimsenin yanında yardımcı yoksa bir işe yaramıyor. Yani Personel eksikliği bulunmaktadır.

K7: Hayır değil ören yerlerinde tekerlekli sandalye yolları yok.

K8: Rampaların düzenli bir şekilde yapılması başarılı olsa da, bunun tüm alanlarda uygulanır olması ve tüm planlamalarda öncelik olarak engelli geçiş, rampa unsurlarının öncelik olması gerekmektedir.

K9: Tam olarak yeterli değil. Farklı engellere yönelik örneğin görememe yada işitmeme ye yönelik farklı metotlar geliştirilebilir.

K10: Değil. Gerekli rampalar ve ya rahat hareket alanı bulunmuyor

K11: Yetersiz. Özellikle yürüme alanları. Asansörler ya da yürüme bantlar1.

K12: Ören yerleri tarihi dokuları itibariyle birçok açıdan engelli ziyaretçiler için uygun değil

K13: Kesinlikle yeterli değildir. Örneğin Efes antik kentinde tekerlekli sandalye kullanan bir kimsenin turu sorunsuz bitirebilmesi mucize olacaktır ki Efes Antik şehri ülkedeki en önemli, en çok misafir ağırlayan turistik destinasyonlardan birisidir.

K14: Yetersiz. Hiçbir camiye giremezler. Topkapı sarayında onlara uygun wc yok. Görme engellilere göre bir broşür bulamazsınız. İşaret diliyle ücretsiz rehberlik hizmeti işitme engelli insanlara verilse keşke

K15: Hayır yeterli değil. Çeşitli yeniliklerle her vatandaşın hakkı olan ziyaret alanlarında engelliler için konfor oluşturulmalı Belirli dönemlerde uzman eğitmenlerce seminerler verilerek farkındalık yaratılmalıdır.

K16: Maalesef! Ülkemizde belki sadece müzelerde engelliler için tekerlekli sandalyeliler için düzenlemeler yapılmış, şehirlerde ve ören yerlerinde hiç düzenleme yok. Mesela işitme engelliler için veya zihinsel engelliler için müzelerde onların anlayabileceği şekilde düzenlemeler yapılabilir.

K17: Henüz yeterli değil, özellikle tuvaletlerin tek oluşu sıkıntı, çift olmalı, unisex olarak en az 2 adete çıkarılmalı.. Parkur tekerlekli sandalyeye uygun olmalı, aksi halde ruhsat kesinlikle verilmemeli.

K18: Çok fazla deneyimim olmasa da genel gittiğim ören yeri için(Efes) eski ve zorlu yollar için daha farklı bir çözüm bulunabilir

K19: Kesinlikle yeterli olmadığını söyleyebilirim. Bunu bedensel engelli (tekerlekli sandalyeli) turiste yönelik cevaplamak isterim. Ören yerlerinde döşeli ahşap gezi yolları her sandalye için uygun değildir. Tekerlekler sıralanmış tahtaların arasına sıkışabilmekte. Bazı alanlarda yere dökülen çakıl taşları da sandalyenin uygun sürüşünü engellemektedir. Bergama antik kenti hiç uygun bir destinasyon değildir. Tahta yollar bir anda düzensiz, kaygan merdivenlerle sonlanabilmekte. Gişe görevlileri engellilere yönelik giriş yönetmeliklerine hakim değildir ( engelli kartına ücretsiz girişin engelliye ve refakatçisine sağlanması gibi).

K20: Sadece bir elin parmaklarını geçmeyecek destinasyonlarda bedensel engelliler için servis söz konusu. 
Tekerlekli sandalye için asansörler gibi. Her destinasyonda işitme engelliler için işaret dilinde açıklama yapan bir ekran olması iyi olurdu

K21: Ziyaret edilen müze yerlerinde çoğu düzenleme engelli turistlere yönelik değildir. Örneğin çoğu yerlere ulaşım merdivenler aracılığıyla sağlanıyor ve engelli bireyler açısından zorluk oluşturuyor

6. Soru Özet Fikir: Bu soruya ilişkin katılımcıların verdikleri yanıtlar incelendiğinde, araştırmaya katılan katılımcıların tamamının engellilere yönelik düzenlemelerin yetersiz olduğunu düşündükleri görülmektedir. Turlarda yaşadıkları deneyimlerden de hareketle özellikle fiziksel engelli misafirlerin yaşadığ vb. eksikliklere değinmişlerdir. Ayrıca katılımcılar sadece fiziksel engellilere yönelik değil farklı engel türlerine yönelik de çeşitli düzenlemelerin yetersiz olduğunu ve bunların hayata geçirilmesinin gerekliliğine değinmişlerdir. Özellikle ören yerlerinde yaşadıkları sorunlara dikkat çeken katılımcılar bazı müzelerin farklı engel türlerine yönelik hizmet verebilme konusunda yeterli olduğunu ancak bunun diğer turistik çekiciliği olan yerler için de uygulanması gerektiğini ifade etmişlerdir.

\section{Tablo 7. Engelli Pazarına Bakış Açısı}

\section{Soru: Seyahat acentalarının bu pazara bakıș açısını nasıl değerlendiriyorsunuz?}

K1: Muhtemelen birçok acenta engelli turizmini daha zahmetli buluyordur.

K2: 10 yıldır turist rehberiyim hocam. Henüz böyle bir paket görmedim.

K3: Yetersiz, uzmanlaşma sağlanıp çok iyi pazarlanabilir.

K4: Bunu bir pazar olarak gören bir seyahat acentasıyla tanışmadım henüz.

K5: Seyahat acenteleri zor olacağını düşünerek çok sıcak bakmazlar.

K6: Araç ve teçhizat hususunda eksikleri olup, maliyetli bir pazar gözü ile görüyorlar (asansörlü araç \& akülü araç için özel bagaj vs ).

K7: Araç ve teçhizat hususunda eksikleri olup, maliyetli bir pazar gözü ile görüyorlar( asansörlü araç \& akülü araç için özel bagaj vs ).

K8: Karlarını daha fazla arttırmak gözüyle, bakış açısıyla bakıyorlar. Yani onlar da; aslında böyle durumlar için kendilerini ve Fizibilite koşullarını, eksiksiz olarak önceden hazırlamadan " ben yaptım oldu " mantığı ile hareket ederek hizmet vermeye devam ediyorlar genelde.

K9: Seyahat acentalarının bu pazardan kazanç elde edemeyeceklerini düşünüp önemsediklerini sanmıyorum.

K10: Uğraşmaya değmeyecek bur pazar olarak gördüğünü düşünüyorum.

K11: Özel ilgi turizmi olarak ele alan pek acenta yok.

K12: Bu konuda tek bildiğim Tura Turizm'in böyle bir tur alternatifi, hatta duruma göre dizaynedilmiş bir tur aracı olduğudur.

K13: Sıcak bakmadıklarını düşünüyorum.

K14: Vakit kaybı ve dikkate alınmaz.

K15: İlgisiz olduklarını düşünüyorum.

K16: Belirli acenteler dışında, çok ilgili olduklarını şuana kadar gözlemlemiş değilim.

K17: Seyahat acentaları turu en ucuza en fazla kişiye nasıl satarım, rehberin kaptanın, otelin, restoranın masrafindan nasıl tasarruf yapabilirim, dağa fazla ek gelir elde edebilmek için rehber'e nerede yemek sattırabilirimin peşinde maalesef.

K18: Bu durum bildirildiğinde fazlası olmasa da ellerinden geleni yaparak günü güzel geçirtmeye çalışıyorlar. Bunun yanında günün en önemli iki unsuru rehber ve kaptan. Bütün günün yükünü yüklenip acentanın da adının iyi duyulması konusunda.

K19: Maalesef acentaların turu satın alan kişinin engelli olup olmadığına dikkat etmek yerine turu satmak odaklı olduklarını görmekteyim. Rehber'in önceden bilgilendirilmemesi de buna işaret etmektedir. Lift olmayan bir aracın tura yönlendirilmesi de oldukça yanlış. Kaptandan engellinin taşınmasını beklemek, bunu kaptanın bir sorumluluğuymuş gibi dayatmak işleri içinden çıkılmaz hallere sokmaktadır. Engelli turizmi eğitiminin acenta çalışanlarından başlayarak, rehberlere genişleyen bir sistemde gerçekleştirilmesi etkili olacaktır.

K20: Bu pazarın yüzdesi çok büyük olduğu düşünmediklerinden gerekli önemin gösterilmediğini düşünüyorum. K21: Seyahat acentaları açısından engelli turizm pazarı iyi bir pazar çoğu seyahat acentası engellilere hizmet vermek istiyor fakat yeterli şartlar sağlanmadığı için bazı zorluklardan dolayı engelli turizmle fazlada uğraşmak istemiyorlar.

7. Soru Özet Fikir: Yedinci soruya ilişkin katılımcıların verdiği yanıtlar benzerlik göstermektedir. Katılımcılar seyahat acentalarının engelli pazarına bakışının olumsuz olduğu görüşünde hemfikirdirler. Bu olumsuz bakış açısının altında yatan nedenlere ilişkin de benzer ifadelerin kullanıldığı ve genel olarak sorunların ortak özellikte olduğu görülmektedir.

Tablo 8. Gelecekte Engelsiz Turizm İçin Gerekenler

8. Soru: Gelecekte daha rahat ve engelsiz bir tur yapabilmeniz için gerekli olan koşullar 


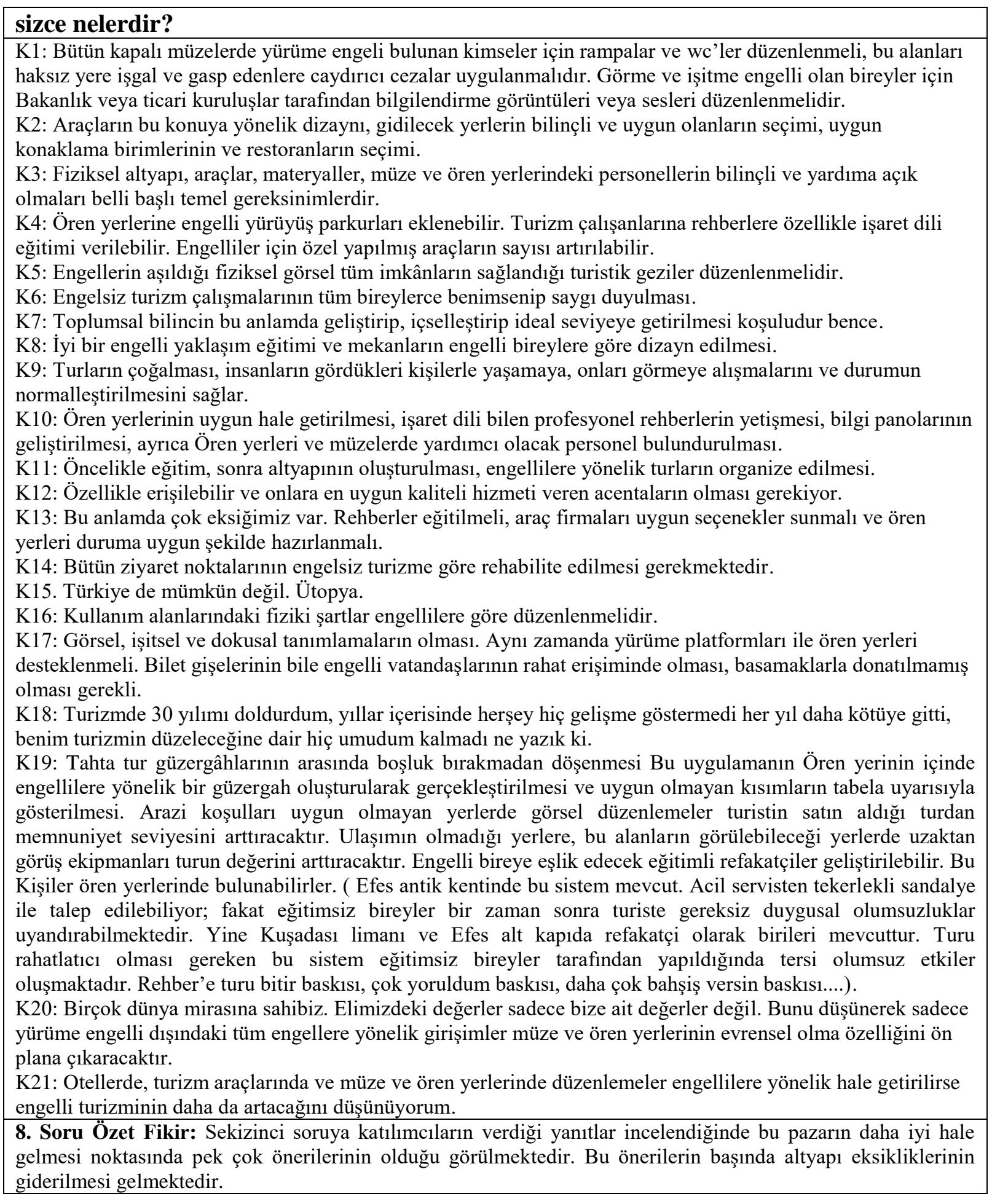




\section{Sonuç}

Engellilik, bireyin yaşam aktivitelerini sınırlayıcı ve kısıtlayıcı zihinsel-fiziksel bozukluklardır. Engelli insanların da engelli olmayan bireylerle aynı ihtiyaçlara sahip olabileceği göz ardı edilmekte veya yok sayılmaktadır. Sosyal yaşama yeterli ölçüde katılamayan engellilerin seyahat etmek ve turizm faaliyetlerinde bulunmak da en temel haklarındandır. Araştırma bulgularına göre katılımcıların genel olarak engelli turizmine ilişkin yeterli bilgi ve anlayışa sahip olduğu söylenebilir. Bazı katılımcıların ise engelli turizmini sadece fiziksel engeli olan bireylerin katıldığı bir turizm şekli biçiminde algıladıkları görülmüştür. $\mathrm{Bu}$ algının oluşmasındaki nedenin, katılımcıların daha çok fiziksel engelli bireyler ile turlarda karşılaşmış olmalarından ve turda yaşanan engellerin ağırlıklı olarak lojistik ve gezi yerlerinde fiziksel engellilere yönelik düzenlemelerin eksik olmasından kaynaklandığı söylenebilir.

Akdu ve Akdu (2018: 119) yaptıkları çalışmada Türkiye 6326 sayılı Turist Rehberliği Meslek Kanunu'nda işaret dili bilen rehberler yanında farklı engel türüne sahip engelli turistlere yönelik hizmet sunabilecek yeterliliğe sahip rehberlerin yetiştirilmesi ve acentelerin engellilere hizmet sunabilecek rehber bulundurulmasına yönelik hükümler bulunmadığı tespit etmişlerdir. Aslında bu konuda yasal düzenlemelerin gerekliliği tekrar tekrar ortaya çıkmaktadır. Yıldız ve diğerleri (2018: 114) yaptıkları çalışmada Kültür ve Turizm Bakanlığı bünyesinde sessiz rehber yetiştirilme gerekliliğini belirtmişlerdir. $\mathrm{Bu}$ bağlamda araştırma içerisinde toplanan verilere bakıldı ğında turist rehberlerinin genel olarak bu konuda verilecek eğitimlere sıcak baktıkları anlaşılmaktadır. Ayrıca sertifikasyon sistemi ile bu gruba özel bir yer verildiği anlaşılacaktır. Wong ve Ap (2001: 557) turist rehberlerinin engelli pazarına yönelik hizmetlerinin düşük seviyede olduğunu belirtmişlerdir. Turist rehberlerinden alınan bilgilerde bu yöndedir ki turist rehberleri bu konuda yapılacak eğitimlere katılacaklarını belirtmişlerdir. Katılımcıların pek çoğu böyle bir eğitim ya da sertifika programına daha önce hiç katılmadıklarını ancak açılması durumunda bu tür eğitimlerin engelli bireylere hizmet sunma noktasında kendilerine büyük katkı sağlayacağını ve katılacaklarını belirtmişlerdir. Ayrıca bu soruya verilen yanıtlarda dikkat çeken bir diğer unsur da her ne kadar böyle bir eğitim almamış olsalar da engelli bireylere hizmet etme noktasında ellerinden geldiğince faydalı olmaya çalıştıkları ve bu konuda motivasyonlarının yüksek olduğudur. Pek çok katılımcı eğitim almamış olmalarına karşın yine de engelli misafïleri ile gerçekleştirdikleri turlarda ellerinden gelenin en iyisini yapmaya çalıştıklarını belirtmişlerdir.

Bulgan (2015: 120) farklı zaman aralıkları ile engelli bireylerin yaşam standartlarını yükseltmeye yönelik çeşitli yasal düzenlemeler yapılmış olunmasına rağmen engelli bireylerin 
henüz dezavantajlı bir grup olarak yaşamlarını sürdürmelerinin önüne geçilemediğini ortaya koymuştur. Evci ve Kuş-Şahin (2017: 688) yaptıkları çalışmada Göreme açık hava müzesinin engelliler için daha düzenli hale getirilmesi için, ulaşımın arttırılması gerektiğini, toplu taşıma araçlarının sayısının arttırılmasının özellikle önemli olduğunu, engelli parkurları oluşturulmasının gerekli olduğunu, engelliler için parkurlar hazırlanarak özel araçlar getirilmesi gerekliliğini belirtmişlerdir. Katılımcılar engelli turizmine yönelik çok az destinasyonda ve turistik çekiciliği olan bölgede çeşitli düzenlemelerin yapıldığını ancak buna karşın Türkiye'nin bu pazara hizmet verme konusunda yetersiz olduğunu belirtmişlerdir. Özellikle turlarda bu pazarı deneyimleme şansı bulan rehberlerin yaşadığı en önemli sorunların başında olması nedeniyle altyapı eksikliklerinin onların turu daha kolay ve sağlıklı gerçekleştirebilmeleri adına büyük önem taşıdığı bu soruya verilen yanıtlarda da tekrar vurgulanmış olmaktadır.

Bir diğer dile getirilen öneri ise eğitimli ve bilinçli personellerin yetiştirilmesidir. Gerek tur rehberlerinin gerekse operasyonun içinde yer alan diğer personellerin ve genelinde toplumun engelli bireylere bakış açısı, onlara yönelik davranış ve tutum konusunda eğitilmeleri ve bu pazara yönelik pozitif bir bilincin geliştirilmesi gerektiğini vurgulamışlardır. Katılımcıların belirttiği diğer öneri ise acentaların bu pazara olan bakış açısını değiştirerek engelli pazarına yönelik araç, gereç, donanım ve hizmet konusunda yeterliliklerini geliştirmeleri ve engelli pazarına özgü tur programları hazırlamalarıdır.

Yani görmezden gelmek yerine iyileştirmek için bir şeyler yapma gerekliliği ortaya çıkmaktadır. Ayrıca Akıncı ve Sönmez (2015: 109) yaptıkları çalışmalarında tatil organizasyonundan tatilin gerçekleştirilmesi aşamasına kadar engellilerin taleplerinin ne olabileceğine dair görüşler arasında en fazla fiziki koşullar konusunda talepler bildirilmiş, bunun yanında refakatçi ihtiyaçlarının olacağına dair görüşler saptamışlardır. Bunların yanında hizmet götürecek kişilerin eğitilmesi konusuna da değinilmesi önemli görülmüştür. $\mathrm{Bu}$ bakımdan turist rehberlerinin önemi bir kez daha ortaya çıkmaktadır. Araştırma bulgularında seyahat acentalarının engelli pazarına yönelik olumsuz bir bakış açısına sahip olmasına yönelik gösterilen temel nedenlerden ilki bu pazarın acentaları açısından karlı ölçekte görülmediğidir. Bir diğer önemli unsur ise engelli pazarına yönelik düzenlenecek turlar için ek teçhizat, donanım ve iş gücü gereksiniminin onlara ek maliyet getirmesinden kaçınmaları olarak işaret edilmiştir. Ayrıca pazarın acentalar tarafından zahmetli bir Pazar olarak değerlendirildiğidir. Seyahat acentaların öncelikli hedefinin çok sayıda tur satmak olduğu ve engelli ya da engelsiz ayrımı yapmaksızın ellerinde mevcut imkânlar yetersiz olsa 
da tur satışlarını gerçekleştirdiklerini ve bu şekilde düzenlenen turların engelli misafirler ve tura rehberlik edenler açısından büyük sıkıntılara yol açtığını belirtmişlerdir.

Büyükşalvarcı ve diğerleri (2017: 261) yaptıkları araştırmada engellilerin harekete geçerek üretken hale gelmelerine, başkalarına bağımlı olmaktan kurtulup bağımsızlaşmalarına toplumun dışında kalmak yerine toplumla bütünleşmelerine, kendilerine güven duymalarına olanak tanımak gerektiğinden bahsetmektedirler. Her bir bireyin engelli adayı olduğu bu bağlamda daha fazla dikkat çeken bir nokta olmalıdır. Buna bağlı olarak önem düzeyinin yükselmesi gerekliliği ortaya çıkmıştır. Yapılan çalışma içerisinde turist rehberleri seyahat acentalarının bu konuda çalışmalar yapmadıklarını belirtmişlerdir. Akıncı ve Sönmez'in (2015: 110) fiziksel engelli katılımcıların özel transfer aracı, işitme engelli katılımcıların ise işaret dili bilen eleman rehber istekleri olduğu sonucuna ulaşılmıştır. Solmaz ve Yenişehirlioğlu (2020: 486) yaptıkları çalışmada teknolojik gelişmelerin ve ulaşım imkânlarının çoğalmasıyla engelli bireylerin her geçen gün turizm endüstrisinde daha fazla misafir olarak yer alacağı belirtmişlerdir. Bunun yanında turizm araştırmacıları ve eğitimcileri olarak engelli bireyleri sadece misafir olarak görmekten ziyade ev sahibi olacakları şekilde yetiştirmek üzerimize düşen görevler olarak belirtmişlerdir. Sosyal farkındalığı arttırmak bu düzeyde karşımıza çıkmaktadır. Ayrıca katılımcılar rehberlik hizmetlerinin ister engelli ister engelsiz bireyler ile gerçekleştirilsin, bir turun sağl1klı biçimde gerçekleştirilebilmesi, kültürlerarası bilgi alışverişinin sağlanabilmesi ve tatminin sağlanması noktasında büyük önem arz ettiğini vurgulamışlardır. Katılımcıların bu soruya ilişkin verdiği yanıtlarda dikkat çektikleri diğer önemli bir unsur ise rehberlerin eğitimli, sabırlı olmasının ve empati ile yaklaşabilmesinin gerçekleştirilen turda tatmini daha da arttıracağıdır.

Rehberlerin engelli bireylere yönelik hizmet verme konusunda ise bilgi ve beceri düzeylerinin henüz arzu edilen seviyede olmadığı ve bu durumun engelli bireylerin tatil tatminini olumsuz yönde etkilediği görülmektedir. Engelli turizminde rehberlere duyulan ihtiyaç ve yılar içinde bu pazarın giderek gelişeceği düşünüldügünde gerek sektör gerekse akademik alanda bu konuya öncelik verilmesi gerektiği açıktır. Sektörde faaliyet gösteren rehberlerde, konuya ilişkin farkındalık yaratılması ve farklı engel türlerine yönelik hizmet verebilmelerini sağlayacak eğitim programlarının düzenlenmesi önerilmektedir. Tur operatörleri ve seyahat acentalarının da rehberlerin engelli bireylere hizmet vermelerini kolaylaştıracak gerekli donanım ve imkânları temin etmeleri rehberlerin bu alana yönelmelerinde ve başarılı biçimde hizmet vermelerinde önem taşımaktadır. Akademik alanda ise rehberlerin engelli turizmindeki yeterlilik düzeylerini, engelli bireylerin rehberlerden beklentilerini, farklı engel türlerinin ihtiyaç duyduğu rehberlik hizmetlerini vb. 
konuları inceleyen ve bu konunun önemine dikkat çeken akademik çalışmaların yapılması önerilmektedir. $\mathrm{Bu}$ doğrultuda gerek devletlerin gerekse turizm sektöründe yer alan tüm işletmelerin engellilerin hareketliliklerini destekleyici bir takım tedbirleri almaları ve onların turizm faaliyetlerinde bulunmalarını kolaylaştırıcı bir etki yaratmaları beklenmektedi 


\section{KAYNAKÇA}

Akınc1, Z. ve Sönmez, N. 2015.Engelli Bireylerin Erişilebilir Turizm Beklentilerinin Değerlendirilmesine Yönelik Nitel Bir Araştırma, Anatolia: Turizm Araştırmaları Dergisi, Cilt 26 (1): 97-113.

Arıc1, S. 2010. Bedensel Engellilerin Turizm Sektöründen Beklentilerinin Tespitine Yönelik Bir Araştırma. Yayımlanmamış yüksek lisans tezi Ankara: Gazi Üniversitesi Eğitim Bilimleri Enstitüsü, Ankara.

Akdu, U. ve Akdu, S. 2018. Engelli Turizmi: Yasal Düzenlemeler ve Uygulamalar. Gümüşhane Üniversitesi Sosyal Bilimler Enstitüsü Dergisi. Cilt 9 (23): 99-123.

Ayyıldız, T., Atay, H. ve Yazııı, A. 2014. Konaklama İşletmelerinin Engelliler İçin Olanakları ve Yöneticilerin Görüşleri: Kuşadası Örneği. Gazi Üniversitesi Turizm Fakültesi Dergisi , (2) , 84-100. Retrieved from https://dergipark.org.tr/en/pub/gaziturizm/issue/48838/622239

Bulgan, G. 2015. Dünya'da veTürkiye'de Engelli Turizmi İle İlgili Yapılan Çalışmalar. Akademik Bakış Uluslararası Hakemli Sosyal Bilimler Dergisi, (50), 102-125. Retrieved from https://dergipark.org.tr/en/pub/abuhsbd/issue/32944/366042. ISSN:1694-528X

Bulgan, G. 2017. Zihinsel Engelli Bireylere Sahip Ailelerin Tatil Deneyimleri Üzerine Tanımlayıcı Bir Araştırma: Isparta İli Örneği. İstanbul Journal of SocialSciences, (16), 35-63.

Büyükşalvarcı, A., Şapçılar, C. M. ve Tuncel, M. 2017. Otel İşletmelerinde Engelli Olanaklarına İlişkin Yöneticilerin Görüşleri.Selçuk Üniversitesi Sosyal ve Teknik Araştırmalar Dergisi Sayl: 13, 2017, ss. 249-263.

Carvalho, I. 2018.The Accessible Tourism in Lisbon, as a Challenge forthe "Art" of Tourist Guiding, Sociology and Anthropology 6(1): 48-55

Chen, R. J. C. 2005. Uses of Hospitality and Leisure Services: Voices of Visitors with Disabilities. Advances in Hospitality and Leisure, 1: 89-102.

Chikuta, O.,Kabote, F. ve Chikanya, N. 2017.Tour Guides Experiences with Tourists with Disabilities, EJTHR $8(2)$

Creswell, J. W. 2013. Research Design: Qualitative, Quantitative, and Mixed MethodsApproaches. New York: Sage

Çizel, B., Sönmez, N. ve Akıncı, Z. 2012. Antalya'da Engelli Turizminin Gelişimi Iç̧in Arz ve Talep Üzerine Bir Araştırma. http://apgem.akdeniz.edu.tr/v2/template/content/projeler/eaet/ciktilar/kitap_engelli_ son_kapali.pdf (Erişim Tarihi: 02.08.2019).

Daniels, M.J.,Rodgers, E.B.D., ve Wiggins, B. 2005. Travel Tales: An Interpretive Analysis Of Constraints and Negotiation Stop Leasure Travel as Experienced by Persons With Physical Disabilities.Tourism Management, 26(6), 919-930

Darcy, S.,Dickson, T., J. 2009. A Whole-of-Life Approach to Tourism: The Case for Accessible Tourism Experiences, Journal of Hospitality and Tourism Management, 16(1):32-44

EuropeanCommission (EU). 2013.DG Enterprise and Industry (DG ENTR) Economic Impact and Travel Patterns of Accessible Tourism in Europe Final Report https://www.academia.edu/7606067/Economic_Impact_and_Travel_Patterns_of_Accessible_Tourism_i n_Europe (Erişim Tarihi: 18.07.2019)

Evci, A. ve Kuş Şahin, C . 2017. Bedensel Engelli Bireylerin Erişilebilir Turizmi Değerlendirmesi Üzerine Bir Araştırma. Nevşehir Bilim ve Teknoloji Dergisi, 6 (2) , 681-689 . DOI: 10.17100/nevbiltek.334625.

Figueiredo, E.,Eusébio, C. ve Kastenholz, E. 2012. How DiverseAreTouristsWithDisabilities? A Pilot Study on AccessibleLeisureTourismExperiences in Portugal. International Journal of TourismResearch, 14(6): 531-550.

McKercher, B.,Packer, T.,Yau, M. K. ve Lam, P. 2003. Travel Agents as FacilitatorsorInhibitors of Travel: Perceptions of People WithDisabilities. Tourism Management, 24: 465-474.

Özoğul, G. ve Güçlütürk Baran, G. 2017.Bir İhtisaslaşma Modeli: Engelliler İçin Ulaşılabilir Turizm Tur Programı ve Tur Fiyatlandırması Örneği,Ulakbilge, 5(15)

Patton, M. Q. 2005. Qualitative Research. New York: John Wiley \& Sons, Ltd

Popiel, M. (2014). Paving The Way To Accessible Tourism On The Example Of Krakow .European Journal of Tourism, Hospitality and Recreation. (Special Issue): 55-71

Poria, Y.,Reichel, A. ve Brandt, Y. 2011. Dimensions of Hotel Experience of People with Disabilities: an Exploratory Study. International Journal of Contemporary Hospitality Management, 23(5): 571-579.

Shaw, G. ve Coles, T. 2004. Disability, Holiday MakingandtheTourismIndustry in The UK: A Preliminary Survey.Tourism Management 25: 397-403.

Solmaz, S. A. ve Yenişehirlioğlu, E. 2020. Turizm Öğrencilerinin Engelli Bireylere ve Engelli Turizmine Baklş Açılarını Belirlemeye Yönelik Bir Araştırma, Türk Turizm Araştırmaları Dergisi, 4(1): 476-487.

Toskay, T. 1989. Turizm Olayına Genel Yaklaşım, Der Yayınları, İstanbul

Türkiye Seyahat Acentaları Birliği (TÜRSAB). 2002. Seyahat Acentaları İhtisas Alanı Anketi-2002 Sonuç Raporu. http://www.tursab.org.tr/dosya/974/23_974_633248.pdf. (Erişim Tarihi: 19.02.2019). 
Web: Kilimci, S. (2008) Turizm Engel Tanımaz (Nisan- Mayıs 5). http://www.tursab.org.tr/tr/engelsizturizm/komite-haberleri/turizm-engel tanimaz_490.html 11.06.2020 tarihinde alınmıştır.

Web: United Nations World TourismOrganization-UNWTO (BM Dünya Turizm Örgütü). 2013.

Recommendations on AccessibleTourism.

http://dtxtq4w60xqpw.cloudfront.net/sites/all/files/docpdf/accesibilityenok.pdf. 12.10.2019 tarihinde alınmıştır.

Web: https://www.who.int/health-topics/disability\#tab=tab_1 11.06.2020 tarihinde alınmıştır.

Web: Samah A.-M., S.-A., Samar M.-K., Heba I. M. Mahran, (2020) The Employment of Technology in Enhancing Special Needs Heritage $\quad$ Tourism https://www.minia.edu.eg/tourism/Files/alaihtiajat\%20alkhasa2.pdf erişim 12.06.2020.

Web: www.accessibletourism.org/.../enat_study_1_ri.(Erişim Tarihi: 01.08.2019).

Wong, K.F. ve Ap, J. 2001.Case Study On TourGuiding: Professionalism, IssuesandProblems, Tourism Management 22(5):551-563

World HealthOrganization-WHO. (Dünya Sağlı Örgütü). 2011. World Report on Disability. http://www.who.int/disabilities/world_report/2011/accessible_en.pdf. (Erişim Tarihi: 05.08.2019).

Yaylı, A., Öztürk, Y. 2006. Konaklama işletmeleri yöneticilerinin b̄edensel engelliler pazarına bakış açıları üzerine bir araştırma. Anatolia: Turizm Araştırmaları Dergisi, 17(1), 87-98.

Yau, M.K.,McKercher, B. ve Packer, T.L. 2004. "TravelingWith A DisabilityMoreThan An Access Issue”. Annals of TourismResearch, 31 (4), 946-960

Yıldız, Z., Yıldız, S. ve Karaçayır, S. 2017. Dünyada ve Türkiye'de Engelli Turizmi Pazarının Değerlendirilmesi,Journal of TourismandGastronomyStudies, 70.

Yıldız, Z., Yıldız, S ve Bozyer, S. 2018. İşitme Engelli Turizmi (Sessiz Turizm): Dünya ve Türkiye Potansiyeline Yönelik Bir Değerlendirme. Süleyman Demirel Üniversitesi Vizyoner Dergisi, 9 (20), 103-117 . DOI: 10.21076/vizyoner.339776.

Zillinger, M.,Jonass, M., and Adolf, P. 2012. GuidedToursandTourism.ScandinavianJournal of HospitalityandTourism, 12 (1), 1-7

Zbikowski, J.,Kuzmicki, M., Dabrowski, D., ve Soroka, A. 2011. Vocational Activity As A Determinant of Participation in Tourism of Disabled People FromtheArea of Eastern Poland.Oeconomia, 10 (2), 121129.

Zajadacz, A. 2014. SourcesOfTourist Information UsedByDeafPeople. Case Study: ThePolishDeafCommunity. CurrentIssues in Tourism, 17 (5), 434-454.

Zeiger, D. 2011. For Travel Agencies, SpecializationKeytoSurviving in Digital Age. http://www.eastvalleytribune.com/money/article_bd153b58-b4ad-11e0-bcdd 001cc4c03286.html?mode=jqm(Erişim Tarihi: 15.07.2019).

Zengin, B. ve Eryılmaz, B. 2013. Bodrum Destinasyonunda Engelli Turizm Pazarının Değerlendirilmesi. International Journal of EconomicandAdministrativeStudies,6(11): 51-74. 